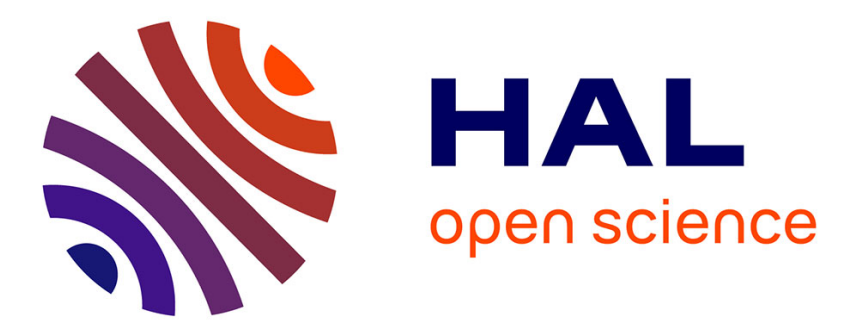

\title{
Significant differences and curvilinearity in the self-thinning relationships of 11 temperate tree species assessed from forest inventory data \\ Marie Charru, Seynave, François Morneau, Michaël Rivoire, Jean-Daniel Bontemps
}

\section{To cite this version:}

Marie Charru, Seynave, François Morneau, Michaël Rivoire, Jean-Daniel Bontemps. Significant differences and curvilinearity in the self-thinning relationships of 11 temperate tree species assessed from forest inventory data. Annals of Forest Science, 2012, 69 (2), pp.195-205. 10.1007/s13595-011-0149-0 . hal-00930719

\section{HAL Id: hal-00930719 https://hal.science/hal-00930719}

Submitted on 1 Jan 2012

HAL is a multi-disciplinary open access archive for the deposit and dissemination of scientific research documents, whether they are published or not. The documents may come from teaching and research institutions in France or abroad, or from public or private research centers.
L'archive ouverte pluridisciplinaire HAL, est destinée au dépôt et à la diffusion de documents scientifiques de niveau recherche, publiés ou non, émanant des établissements d'enseignement et de recherche français ou étrangers, des laboratoires publics ou privés.

$$
\text { Copyright }
$$




\title{
Significant differences and curvilinearity in the self-thinning relationships of 11 temperate tree species assessed from forest inventory data
}

\author{
Marie Charru • Ingrid Seynave • François Morneau • \\ Michaël Rivoire • Jean-Daniel Bontemps
}

Received: 24 May 2011 / Accepted: 7 September 2011 /Published online: 11 November 2011

(C) INRA / Springer-Verlag France 2011

\begin{abstract}
- Introduction In pure and even-aged stands, the allometry between mean tree size and maximum stand density-or
\end{abstract}

\section{Handling Editor: Daniel Auclair}

Contribution of the co-authors Marie Charru performed data analysis and wrote the manuscript. Ingrid Seynave participated in the data analysis, and discussions, writing and evolution of the manuscript. François Morneau provided the NFI data and associated expertise for their correct exploitation. Michaël Rivoire helped in the technical use of the stochastic frontier analysis. Jean-Daniel Bontemps supervised the whole project, provided statistical expertise on sampling designs, tests, and use of the stochastic frontier analysis, and helped with the redaction. Ingrid Seynave, Francois Morneau and Jean-Daniel Bontemps contributed to the revision and amelioration of the manuscript.

M. Charru $\cdot$ M. Rivoire $\cdot$ J.-D. Bontemps $(\bowtie)$

AgroParisTech, ENGREF, Equipe Ecologie Forestière, UMR 1092 Laboratoire d'Etude des Ressources Forêt-Bois (LERFoB),

14 rue Girardet,

54000 Nancy, France

e-mail: jean-daniel.bontemps@engref.agroparistech.fr

M. Charru

e-mail: marie.charru@gmail.com

M. Rivoire

e-mail: michael.rivoire@gmail.com

M. Charru $\cdot$ I. Seynave $\cdot$ J.-D. Bontemps

INRA, Centre de Nancy, UMR 1092 Laboratoire d'Etude des

Ressources Forêt-Bois (LERFoB),

54280 Champenoux, France

I. Seynave

e-mail: seynave@nancy.inra.fr

F. Morneau

Inventaire Forestier National, Direction Technique,

Château des Barres,

45290 Nogent-sur-Vernisson, France

e-mail: francois.morneau@ifn.fr self-thinning relationship-has long been considered a constant among tree species. Although the self-thinning allometric coefficient has been shown to be speciesdependent, estimates available for a given species also differ. Whether this coefficient truly varies across species thus remains an open issue. A potential cause of variation in the coefficient may lie in a departure from the allometric assumption in the self-thinning relationship.

- Methods We analysed the species dependence of the self-thinning relationship for 11 temperate and Mediterranean tree species growing in pure and even-aged stands in France based on the French National Forest Inventory (NFI) data. Self-thinning relationships were fitted using a 'stochastic frontier' technique. Pairwise comparison tests of the self-thinning allometric coefficients were implemented. We also investigated the allometric nature of the relationship by testing a linear and a curvilinear model of $\log$ density against the $\log$ quadratic mean diameter.

- Results Self-thinning relationships were clearly evidenced from the NFI data and displayed significant differences between species. The curvilinear model was significantly more accurate for 7 out of 11 species and depicted a concave relationship, suggesting a decrease in self-tolerance over ontogeny.

- Conclusion As a major finding, the self-thinning relationship significantly varies across species. We emphasise the need to consider a high number of species to show such specific variations in the self-thinning relationship. Another important outcome is that the self-tolerance depends on the developmental stage.

Keywords Self-thinning · Allometry · Self-tolerance · Stochastic frontier analysis - Law of maximum - National forest inventory 


\section{Introduction}

In forest stands, tree growth can lead to overcrowding and natural mortality - a phenomenon known as self-thinning. Reineke (1933) first showed the allometric nature of the relationship between average tree diameter and maximum stand density in pure and even-aged stands. He found a common allometric coefficient of -1.605 for a variety of tree species. In a wide range of herbaceous species, Yoda et al. (1963) also proposed a single allometric law relating mean plant weight to population density (' $-3 / 2$ power law' or self-thinning rule). Although this law has also been shown to apply to tree species (White 1980, Bi 2004), Zeide (2010) has pointed out that self-thinning in tree species is rather driven by increasing crown width, and maximum density is therefore better related to diameter than to volume or biomass. Hereafter, the relationship between mean tree size and stand density is generally termed the 'self-thinning relationship'.

The invariance of the self-thinning allometric coefficient among plant species has been shown experimentally (Gorham 1979; Le Goff et al. 2010). The uniqueness of the allometry between mean tree weight and stand density has also been theoretically highlighted (Enquist 2002). However, many reported estimates of the self-thinning allometric coefficient significantly differ from Reineke's -1.605 (Pretzsch and Biber 2005) or Yoda's -3/2 (Weller 1987). In addition, recent studies have laid emphasis on specific variations in the self-thinning relationship (Pretzsch 2006; Puettmann et al. 1993; Zeide 2010). Nevertheless, the reality of these reported specific variations remains questioned as differences in the allometric coefficient estimates have been found even within a single species. For example, in Fagus sylvatica L., it was found to be -1.67 by Le Goff and Ottorini (1999) and -1.79 by Pretzsch and Biber (2005).

Confusion in estimating the self-thinning relationship may have several causes. The first is an issue of definition. Weller (1990) distinguished between the species boundary line defined as 'the upper boundary of possible yielddensity combinations for a species, using data from the most extreme of several hundred stands' and the dynamic thinning line that represents 'the time trajectory of an individual crowded stand'. These two lines may have different slopes for a given species (Weller 1990). They also rely on empirical data of differing nature for their estimation.

Second, the scarcity of overstocked plots in managed forest resources is a major limitation to estimating the self-thinning relationship. Most often, data arise from thinning experiments where control plots are left under natural thinning. Although these stands provide accurate records of dynamic self-thinning trajectories, they are irrelevant for establishing the species boundary line (Pretzsch 2006).

Third, methods used to estimate self-thinning relationships (OLS regression, PCA, quantile regression; Puettmann et al. 1993; Zhang et al. 2005) result in considerable variation in the fits obtained (Pretzsch 2009). Stochastic frontier analysis (SFA; Aigner et al. 1977) is a regression method for data edge analysis that can be applied to every situation where the purpose is to estimate the conditional maximum of a dependent variable, observable in only a fraction of the individuals taken in 'optimal' conditions. SFA is thus an especially relevant technique for estimating the self-thinning relationship from data where only a fraction of plots undergoes self-thinning (Bi et al. 2000).

Fourth, the allometric nature of the self-thinning relationship has also been questioned, with a potential increase in the self-thinning rate (or self-tolerance; Zeide 1985) over ontogeny (Pretzsch 2006; Schütz and Zingg 2010; Zeide 2010). Biologically, this has been interpreted with respect to senescence processes and the lower capacity to fill the wider gaps created by increasingly bigger dead trees (Zeide 2010). Such a curvature may cause variations in the selfthinning allometric coefficients reported for a given species and challenges interspecific comparisons (Pretzsch 2006; Zeide 1985) for which calibration datasets do not encompass the same diameter range. Based on geometrical reasoning regarding the spatial occupancy of tree crowns and their relationship to tree diameter, a self-thinning model that displays such a curvature has been developed by Nilson (1973) (cited in Zeide 2010). In this model, the maximum stand density is expressed as a hyperbolic function of the squared mean diameter. The generated self-thinning relationship curves downward with diameter on a $\log -\log$ scale, and it was found to fit the data better than Reineke's model (Zeide 2010). Recently, secondorder polynomials were also found to provide more accurate fits than linear relationships (Pretzsch 2006; Schütz and Zingg 2010).

In this study, we tested the species dependence of the self-thinning relationship, defined as the relationship between the $\log$ stand density $(\ln N)$ and the $\log$ quadratic mean diameter $\left(\ln D_{\mathrm{g}}\right)$. We focused on the species maximum boundary (sensu Weller 1990) for 11 temperate and Mediterranean tree species in pure and even-aged stands in France. We used National Forest Inventory (NFI) data that have never been used for estimating self-thinning relationships, to the best of our knowledge. The NFI data rely on a random systematic sampling of the forested area. Consequently, they are representative of the entire range of conditions where species are encountered in the forest resource, allowing fits of-and comparisons amongaverage self-thinning relationships in these species. A working assumption was that a fraction of the NFI plots 
are located in stands undergoing density-dependent mortality over the species mean diameter range observed. We applied the SFA statistical method. We first fitted linear relationships between $\ln N$ and $\ln D_{\mathrm{g}}$ and tested for between-species differences in the allometric coefficient of self-thinning using multiple pairwise comparison tests. Because apparent differences in this coefficient estimates reported for a given species may be due to a curvature in the self-thinning relationship, we also investigated potential departure from the allometric assumption and tested for an extended curvilinear relationship of self-thinning.

\section{Materials}

We used three inventory cycles of the French NFI, collected between 1976 and 2004. The sampling relies on a systematic grid $(\sim 1 \times 1 \mathrm{~km})$ repeated around every 12 years in each 'département' administrative unit (Robert et al. 2010). NFI plots are organised into four circular concentric subplots. Stand attributes are assessed in a 25-m radius plot. Tree inventories are exhaustive over a threshold diameter at breast height (dbh) of $7.5 \mathrm{~cm}$ in three concentric subplots of radii 6,9 and $15 \mathrm{~m}$, used to measure small (dbh from 7.5 to $22.4 \mathrm{~cm}$ ), medium (dbh from 22.5 to $37.4 \mathrm{~cm}$ ) and large trees (dbh over $37.5 \mathrm{~cm}$ ), respectively. A relative area weight is attributed to each subplot to obtain quantities per hectare. The measured variables include dbh and vegetative state (living, dead, harvested).

We selected pure and even-aged plots of 11 broadleaved and coniferous species: common beech (F. sylvatica L.), sessile oak (Quercus petraea Liebl.), pedunculate oak (Quercus robur L.), pubescent oak (Quercus pubescens Willd.), Scots pine (Pinus sylvestris L.), Aleppo pine (Pinus halepensis Mill.), maritime pine (Pinus pinaster Aiton.), Corsican pine (Pinus nigra Arn. subsp. laricio (Poir.) Maire var. Corsicana (Loud.) Hyl.), Douglas fir (Pseudotsuga menziesii Franco.), silver fir (Abies alba Mill.) and Norway spruce (Picea abies Karst.). The samples cover the entire distribution of these species in France. Stand pureness was controlled by selecting plots where species represented over $90 \%$ of the plot basal area. Even-aged stands were selected using information on the forest structure available in the NFI data. We further discarded open forests where the total cover was $<50 \%$ of the stand basal area and that would be of no interest for the purpose of estimating self-thinning relationships.

The NFI countable threshold at $\mathrm{dbh}=7.5 \mathrm{~cm}$ may lead to the underestimation of stand density for smalldiameter stands and prevent the identification of those undergoing self-thinning. For the sake of caution, we therefore rejected plots under a quadratic mean diameter of $15 \mathrm{~cm}$. In addition, we enquired whether putative self-thinning conditions may be found for all size classes over the $15-\mathrm{cm}$ diameter threshold. We divided the observed $\ln D_{\mathrm{g}}$ into 20 classes and rejected those whose average mortality rate (the ratio between the number of dead trees documented over the last 5 years and the initial number of trees) in the densest $10 \%$ of plots was null at both extremities of the $\ln D_{\mathrm{g}}$ distribution. Depending on species, this criterion led us to increase the lower diameter threshold by $1-5 \mathrm{~cm}$ and to set an upper diameter threshold (from 33 to $50 \mathrm{~cm}$; see Table 1). This precaution was intended to discard diameter classes where self-thinning was not likely to occur and not to select stands experiencing self-thinning. The mortality rates in the densest $10 \%$ of plots for each retained $\ln D_{\mathrm{g}}$ class averaged $2.45 \%$ over all species $(1-5 \%$ depending on the species), whereas it amounts to $1.89 \%$ in the whole dataset (0.7-2.9 depending on the species).

In order to avoid potential imbalances between site conditions and diameter, we analysed the distribution of the quadratic mean diameter (three classes) within each type of French biophysical classification of the forested area (Inventaire Forestier National 2009; http://cartoser.ifn.fr/ carto/afficherCarto) covered by each species. This classification follows the usual specifications of the land and resource classification approach (Bailey et al. 1978). The first level is based on a subdivision of France according to macroclimatic, geological and topographical criteria (11 classes). The second is based on the ecological and floristic NFI data and combines: (1) a refined subdivision of the territory in homogeneous areas regarding climate, topography, geology, soil characteristics and flora and (2) an aggregation of the NFI 'forest habitat types'. This classification resulted in the definition of 86 biophysical areas. For each species, biophysical areas where the three diameter classes were not represented were rejected from the analysis (from 5 to 31 areas, corresponding to $1-$ $20.7 \%$ of the plots; Table 1). The final number of plots exceeded 1,000 for all species, except for Aleppo pine, pubescent oak, Corsican pine and Douglas fir (between 300 and 960; Table 1).

\section{Methods}

\subsection{Stochastic frontier analysis}

The SFA technique (Aigner et al. 1977) consists in fitting the maximum boundary (or frontier) of a predicted variable $(Y)$ conditionally on the predictors. The principle is to assume a left-tailed distribution for the residuals, which features a law of maximum and allows positioning of the maximum boundary onto the data. In the SFA in particular, 
Table 1 Main characteristics of the NFI plots selected to estimate the self-thinning relationships (see Section 3)

\begin{tabular}{|c|c|c|c|c|c|c|c|c|c|c|c|}
\hline & \multirow[t]{2}{*}{$\begin{array}{l}\text { No. of } \\
\text { plots }\end{array}$} & \multicolumn{3}{|c|}{$\begin{array}{l}\text { Stand density } \\
\text { (trees/ha) }\end{array}$} & \multicolumn{3}{|c|}{$\begin{array}{l}\text { Quadratic mean } \\
\text { diameter }(\mathrm{cm})\end{array}$} & \multirow{2}{*}{$\begin{array}{l}\text { Lower } \\
\text { diameter } \\
\text { threshold }\end{array}$} & \multirow{2}{*}{$\begin{array}{l}\text { Upper } \\
\text { diameter } \\
\text { threshold }\end{array}$} & \multirow{2}{*}{$\begin{array}{l}\text { Mean } \\
\text { pureness } \\
(\%)\end{array}$} & \multirow{2}{*}{$\begin{array}{l}\text { No. of removed } \\
\text { ecological areas } \\
\text { (\% of plots removed }\end{array}$} \\
\hline & & Mean & Min & Max & Mean & Min & Max & & & & \\
\hline Pubescent oak & 429 & 630.3 & 39.3 & $1,984.5$ & 21.2 & 15.0 & 36.5 & 15.0 & 37.0 & 98.6 & $14(9.8)$ \\
\hline Pedunculate oak & 1,244 & 481.0 & 39.3 & $2,205.0$ & 26.0 & 15.1 & 36.9 & 15.0 & 37.0 & 97.7 & $11(2.2)$ \\
\hline Sessile oak & 1,110 & 649.5 & 39.3 & $2,544.5$ & 23.0 & 15.0 & 30.0 & 15.0 & 30.0 & 97.5 & $19(3.7)$ \\
\hline Common beech & 2,409 & 589.4 & 14.1 & $2,710.3$ & 27.3 & 16.0 & 40.0 & 16.0 & 40.0 & 98.1 & $18(2.2)$ \\
\hline Scots pine & 3,995 & 782.4 & 39.3 & $3,301.0$ & 22.2 & 15.0 & 33.0 & 15.0 & 33.0 & 98.7 & $19(2.7)$ \\
\hline Aleppo pine & 698 & 499.7 & 28.3 & $2,672.2$ & 23.5 & 15.0 & 40.0 & 15.0 & 40.0 & 99.3 & $5(2.2)$ \\
\hline Corsican pine & 357 & 566.5 & 67.6 & $1,945.2$ & 30.5 & 18.0 & 49.8 & 18.0 & 50.0 & 98.7 & $31(20.7)$ \\
\hline Maritime pine & 5,153 & 524.4 & 39.3 & $3,517.1$ & 26.3 & 16.0 & 37.0 & 16.0 & 37.0 & 99.3 & $10(0.7)$ \\
\hline Norway spruce & 1,301 & 756.1 & 42.4 & $3,652.3$ & 29.2 & 15.0 & 45.0 & 15.0 & 40.0 & 97.9 & $17(3.2)$ \\
\hline Silver fir & 1,778 & 653.3 & 70.7 & $2,908.0$ & 29.6 & 15.0 & 44.9 & 15.0 & 45.0 & 97.5 & $10(1.0)$ \\
\hline Douglas fir & 957 & 632.8 & 28.3 & $2,661.2$ & 28.1 & 20.0 & 49.6 & 20.0 & 50.0 & 99.1 & $11(4.2)$ \\
\hline
\end{tabular}

a two-component error distribution is assumed in $Y$. The first component is a left-tailed error term representing negative deviations that cause departure from the maximum level in $Y$. The second is a classical error term with a symmetric distribution of comparatively low variance, representing random deviations around $Y$. The result is a left-tailed (and possibly modal) distribution. In its simplest form, the stochastic frontier model can be written as

$Y=\beta \mathbf{X}+(v-u)$

where $Y$ is the predicted variable, $\mathbf{X}$ is a matrix of predictors, $\boldsymbol{\beta}$ is a parameter vector to be estimated, and $v$ and $u$ are the symmetric and right-tailed asymmetric error terms, respectively, assumed to be independent of each other and independently and identically distributed across observations (Coelli 1996). The error component $u$ is positive and modelled as the right side of the truncation at quantile zero of a normal distribution $N\left(\mu, \sigma_{u}^{2}\right)$ (Coelli 1996). $\mu$ can be 0 (resulting in a half-normal distribution) or can take positive or negative values (resulting in a modal or monotonic distribution, respectively). The second error component $v$ is assumed to be normal with zero mean and constant variance $\sigma_{v}^{2}$.

Battese and Corra (1977) further proposed the following parameterization:

$\sigma^{2}=\sigma_{u}^{2}+\sigma_{v}^{2}$

$\gamma=\sigma_{u}^{2} / \sigma^{2}$

$\gamma$ lies between 0 and 1 and indicates the relevance of a stochastic frontier model: a small $\gamma$ indicates that the symmetric random error prevails, whereas a high $\gamma$ indicates the significance of the asymmetric error component. As a salient aspect of the SFA methodology, no prior assumption is required on $\sigma^{2}$ and $\gamma$. They are estimated in the statistical criterion optimization (see below), which makes the approach flexible.

\subsection{SFA model for self-thinning}

Maximum stand density is expressed as a function of the quadratic mean diameter. At a given developmental stage, this measure reflects both the oriented effects of site occupancy by trees due to growth and density-dependent mortality and the effects of random external factors such as management, climatic variations, diseases, or plot history (Bi et al. 2000; Weiskittel et al. 2009). Assuming a linear self-thinning relationship, Eq. 1 is therefore specified as

$\ln N=a+b \ln D_{\mathrm{g}}+(v-u)$

where $a$ and $b$ are parameters of the self-thinning line, and $v-u$ is the composite error term whose parameters are estimated in the procedure.

We then tested for the significance of a curvature with the quadratic mean diameter. Following Schütz and Zingg (2010), we tested the effect of an additional quadratic term:

$\ln N=a+b \ln D_{\mathrm{g}}+c\left(\ln D_{g}\right)^{2}+(v-u)$

Parameters $a, b, c, \sigma^{2}, \gamma$ and $\mu$ were estimated by maximum likelihood using the package 'frontier' version 0.996-10 (Coelli and Henningsen 2010) implemented in R software (R Development Core Team 2009). The significance of all parameters was assessed using standard Student's $t$ tests. The adequacy of a stochastic frontier model to represent the data better than a traditional OLS regression, i.e. the 
significance of the composite error term skewness (Bi 2004), was tested using a chi-square likelihood ratio test for nested models (Coelli 1995), hereafter denoted as LRT ${ }_{1}$. To further assess whether a truncated normal distribution for $u$ was more appropriate than a half-normal distribution (significance of $\mu$ ), we computed a second likelihood ratio test $\left(\mathrm{LRT}_{2}\right)$ relative to a model with $\mu=0$ (Bi 2004). The significance of an additional quadratic term in the selfthinning relationship (Eq. 4) was assessed from a comparison with the simpler model (Eq. 3) using a third likelihood ratio test $\left(\mathrm{LRT}_{3}\right)$. In cases where the linear term was no longer significant, $\mathrm{LRT}_{3}$ could not be applied (same number of parameters). Therefore, we performed an Akaike information criterion (AIC) comparison to assess model improvement due to the quadratic term.

When linear self-thinning relationships were fitted (Eq. 3), exhaustive between-species pairwise comparisons of slope estimates were performed using bilateral Student's $t$ tests. Based on these comparisons, groups of species significantly differing with respect to their allometric coefficient estimates were built. When fitting quadratic relationships (Eq. 4), we calculated their first derivatives with respect to the quadratic diameter (slope of the tangent denoted $S$ ), given by

$S=b+2 c \ln D_{g}$

where $b$ and $c$ are the parameters given in Eq. 4. We plotted and compared them over a $D_{\mathrm{g}}$ range between 15 and $50 \mathrm{~cm}$.

\section{Results}

\subsection{Linear self-thinning relationships}

The notion of a maximum in the relationship between $\ln N$ and $\ln D_{\mathrm{g}}$ was clearly identified in the NFI data (Fig. 1). Table 2 summarises the fits of linear self-thinning relationships. The intercept and slope were highly significant for all species. $\mathrm{LRT}_{1}$ was significant for all species $\left(p<10^{-15}\right.$, except for Corsican $\left(<10^{-7}\right)$ and Aleppo $\left(<10^{-8}\right)$ pines), indicating that the error distribution was strongly asymmetric. The estimate for $\mu$ was around -2 , which significantly improved the models according to the $\mathrm{LRT}_{2}$ ( $p$ from $10^{-2}$ to $10^{-15}$ ) in all cases, except Corsican and Aleppo pines ( $p=0.05$ and 0.67 , respectively). For these two species, a truncated normal distribution was no more adequate than a half-normal distribution.

Figure 2a depicts the self-thinning lines fitted for all species. The three oak species, as well as the Aleppo and maritime pines, reached similar maximum densities that were all below those of the other coniferous species. Common beech had an intermediate position: it neighboured species of the highest densities for small diameters and those of lowest densities for larger diameters. The slopes of the self-thinning lines are compared visually in Fig. 2b, by removing the intercept to Eq. 1. Table 3 summarises significant differences in the slope estimates between different species resulting from the $t$ test procedure. We could define four groups of species between which the slope estimates significantly differed (Tables 3 and 4). The groups were not strongly overlapping, and it was also possible to identify exclusive species groups showing no overlap (Table 4).

\subsection{Quadratic self-thinning relationships}

Three different patterns were observed when fitting quadratic self-thinning relationships (Table 5). (1) For Corsican pine, and the three oak species, the quadratic term was not significant according to $\mathrm{LRT}_{3}$ and the linear relationship model was retained. (2) For Douglas fir, silver fir and Scots pine, the quadratic term in $\ln D_{\mathrm{g}}$ significantly improved the models according to $\operatorname{LRT}_{3}\left(p<10^{-4},<10^{-9}\right.$ and $<10^{-7}$, respectively) and always had a negative coefficient indicating a concave self-thinning relationship. (3) For common beech, Norway spruce, maritime pine and Aleppo pine, the quadratic term was also negative and significant according to $\mathrm{LRT}_{3}\left(p=3.10^{-4}, 0.02,7.10^{-4}\right.$ and 0.01 , respectively), but the linear term in $\ln D_{\mathrm{g}}$ was no longer significant according to the $t$ test and was discarded. The AIC difference $(\leq 4)$ between the latter model and the linear one confirmed the usefulness of a quadratic term (Burnham and Anderson 2002). LRT $_{1}$ remained highly significant for all species and $\mu$ again amounted to around -2 for all species, with the exception of Corsican and Aleppo pine, for which it was not significant according to $\mathrm{LRT}_{2}$.

The relative position of the curves fitted with the quadratic self-thinning relationships provided indications similar to those obtained with linear relationships (Fig. 3). The curvature of the self-thinning relationship varied from very strong for Douglas fir and Scots pine, to flat for Corsican pine, and the three oak species (non-significance of the quadratic term). Given the strong curvature in some of these relationships, comparisons of the slopes at a given quadratic diameter were necessary (Fig. 4). The strongest curvature was observed for Scots pine and Douglas fir whose slopes decreased by approximately $200 \%$ over their diameter range (Fig. 4). The slope of silver fir also steepened with $D_{\mathrm{g}}(-180 \%$, Fig. 4). The curvature was of a similar amplitude for common beech, Aleppo pine, Norway spruce and maritime pine (around -35\%, Fig. 4). Among these species, beech and Aleppo pine had the steepest slopes, followed by Norway spruce and maritime pine. The slopes of Corsican pine and the three oak species remained constant across developmental stages. Consequently, species ranking according to self-tolerance was dramatically modified between early and late developmental stages (Fig. 4). 

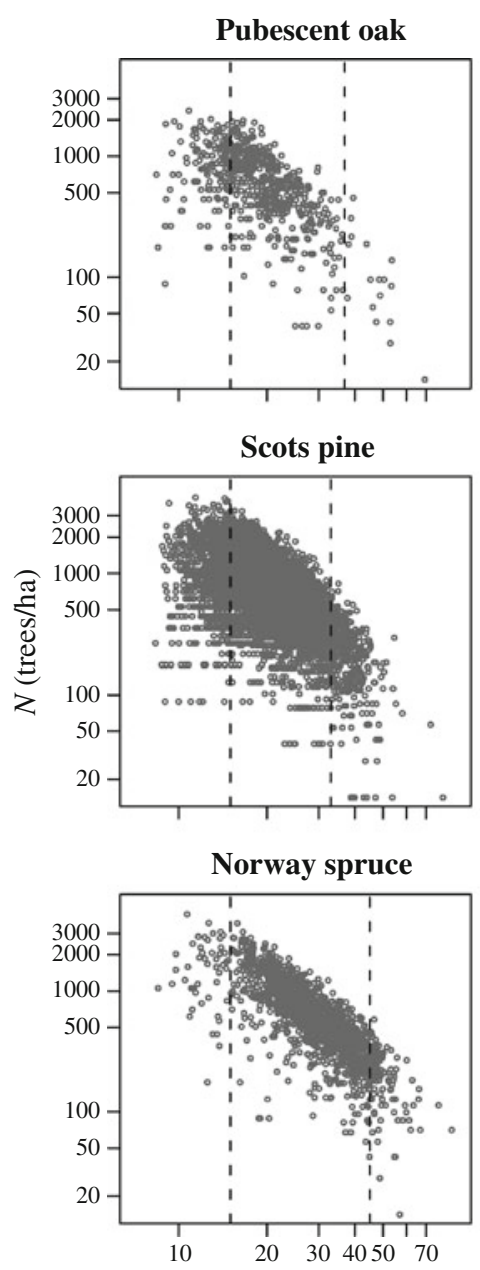
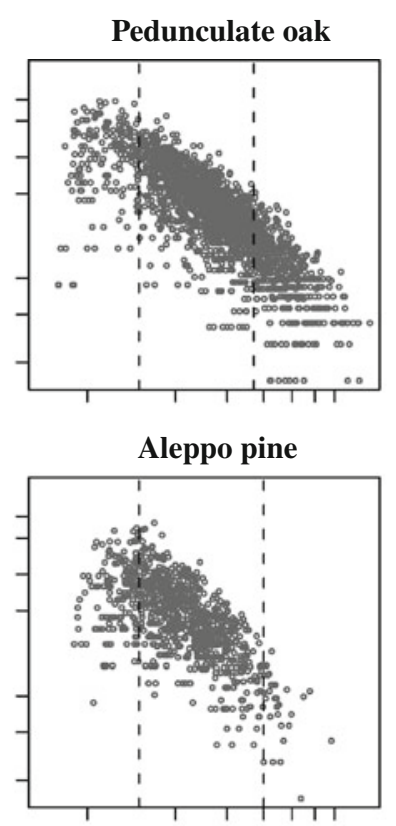

Silver fir

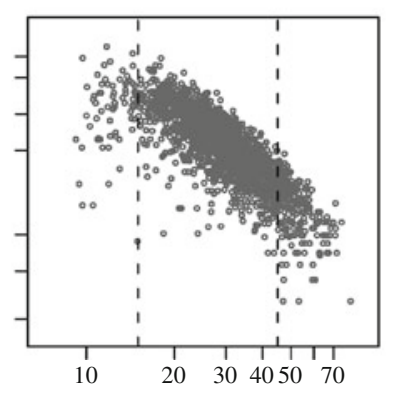

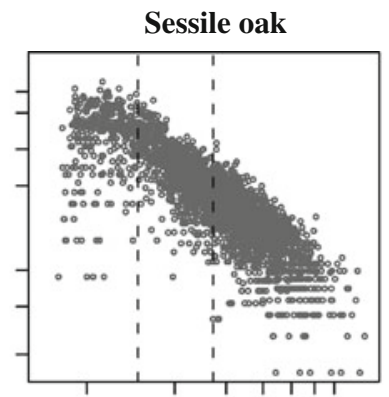

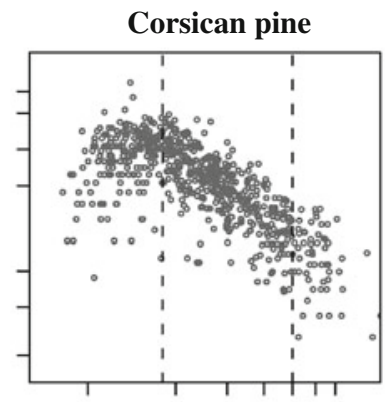

Douglas fir

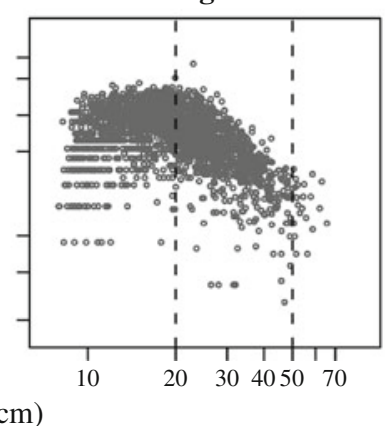

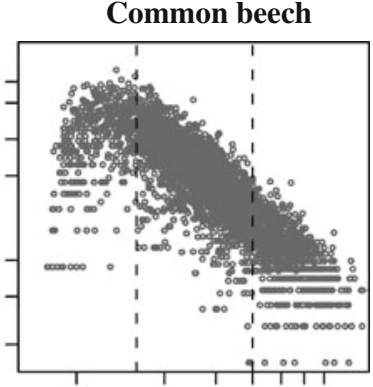

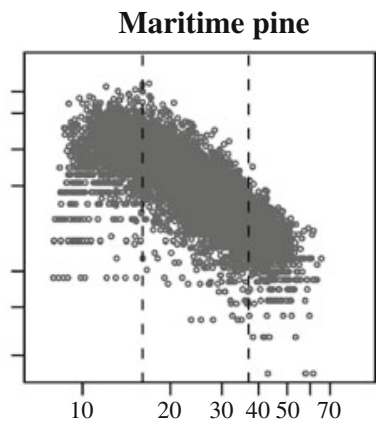

$D g(\mathrm{~cm})$

Fig. $1 N-D_{\text {g }}$ relationships for the 11 temperate and Mediterranean species studied, plotted on a log-log scale. Dashed lines represent the upper and lower diameter thresholds

\section{Discussion}

We tested whether the self-thinning relationship varied among tree species. Because nonlinearity in this relationship may cause apparent differences in the allometric coefficient estimates reported for a given species, we also tested the linearity of this relationship. We used a homogeneous dataset based on NFI data for 11 temperate and Mediterranean species and estimated self-thinning relationships using stochastic frontier analysis (SFA), a relevant technique for assessing conditional laws of the maximum.

\subsection{Suitability of NFI data to estimate self-thinning relationships}

NFI data have never been used to fit self-thinning relationships. For all species, realistic raw $\ln N-\ln D_{\mathrm{g}}$ relationships were found (Fig. 1). Concern for selfthinning conditions to be found along the entire range of diameters considered led us to set upper/lower thresholds on the quadratic mean diameter based on two criteria: (1) avoid plots where stand density could be underestimated (NFI lower countable threshold) and where it may result in an artificial curvature of the $\ln N-$ $\ln D_{\mathrm{g}}$ relationship at low diameters (Schütz and Zingg 2010) and (2) observe true mortality in the densest $10 \%$ of plots for each $\ln D_{\mathrm{g}}$ class. The observed mortality rates $(2.45 \%$ on average over the last 5 years) indicated that selfthinning conditions were likely, even if they constituted no formal evidence for it. Our aim was only to discard diameter classes where self-thinning was not likely to occur and not to select stands experiencing self-thinning. The diameter ranges selected were sometimes very restricted (e.g. sessile oak) because no mortality could be observed in large diameter classes, which is a limit of NFI data.

\subsection{Control of site conditions}

The intercept of the self-thinning relationship has been shown to depend on site fertility (Bi 2004; Weiskittel et al. 
Table 2 Parameter estimates and goodness of fits for linear models of self-thinning relationships

\begin{tabular}{|c|c|c|c|c|c|c|c|c|}
\hline & Intercept (trees/ha) & $\ln D_{\mathrm{g}}(\mathrm{cm})$ & $\sigma^{2}$ (trees/ha) & $\log \operatorname{Lik}$ & $\gamma$ & $\mathrm{LRT}_{1}$ & $\mu($ trees $/$ ha $)$ & $\mathrm{LRT}_{2}$ \\
\hline Pubescent oak & $\begin{array}{r}12.270 \\
0.283\end{array}$ & $\begin{array}{r}-1.809 \\
0.094\end{array}$ & $\begin{array}{l}2.190 \\
1.285\end{array}$ & -316.683 & $\begin{array}{l}0.971 \\
0.017\end{array}$ & $* * *$ & $\begin{array}{r}-2.917 \\
2.470\end{array}$ & $*$ \\
\hline Pedunculate oak & $\begin{array}{r}12.138 \\
0.161\end{array}$ & $\begin{array}{r}-1.758 \\
0.049\end{array}$ & $\begin{array}{l}1.731 \\
0.401\end{array}$ & -820.640 & $\begin{array}{l}0.965 \\
0.009\end{array}$ & $* * *$ & $\begin{array}{r}-2.585 \\
0.865\end{array}$ & $* * *$ \\
\hline Sessile oak & $\begin{array}{r}12.681 \\
0.181\end{array}$ & $\begin{array}{r}-1.911 \\
0.058\end{array}$ & $\begin{array}{l}1.238 \\
0.198\end{array}$ & -562.624 & $\begin{array}{l}0.961 \\
0.009\end{array}$ & $* * *$ & $\begin{array}{r}-2.181 \\
0.503\end{array}$ & $* * *$ \\
\hline Common beech & $\begin{array}{r}12.950 \\
0.110\end{array}$ & $\begin{array}{r}-1.941 \\
0.034\end{array}$ & $\begin{array}{l}1.321 \\
0.143\end{array}$ & -1451.857 & $\begin{array}{l}0.946 \\
0.008\end{array}$ & $* * *$ & $\begin{array}{r}-2.236 \\
0.356\end{array}$ & $* * *$ \\
\hline Scots pine & $\begin{array}{r}11.993 \\
0.125\end{array}$ & $\begin{array}{r}-1.615 \\
0.039\end{array}$ & $\begin{array}{l}1.338 \\
0.322\end{array}$ & $-3,137.467$ & $\begin{array}{l}0.933 \\
0.013\end{array}$ & $* * *$ & $\begin{array}{r}-1.324 \\
0.689\end{array}$ & $* * *$ \\
\hline Aleppo pine & $\begin{array}{r}12.512 \\
0.277\end{array}$ & $\begin{array}{r}-1.881 \\
0.081\end{array}$ & $\begin{array}{l}0.612 \\
0.166\end{array}$ & -562.740 & $\begin{array}{l}0.861 \\
0.036\end{array}$ & $* * *$ & $\begin{array}{l}0.200 \\
0.407\end{array}$ & $n s$ \\
\hline Corsican pine & $\begin{array}{r}12.104 \\
0.211\end{array}$ & $\begin{array}{r}-1.653 \\
0.065\end{array}$ & $\begin{array}{l}1.166 \\
0.477\end{array}$ & -204.123 & $\begin{array}{l}0.936 \\
0.025\end{array}$ & $* * *$ & $\begin{array}{r}-2.089 \\
1.357\end{array}$ & $n s$ \\
\hline Maritime pine & $\begin{array}{r}11.982 \\
0.079\end{array}$ & $\begin{array}{r}-1.711 \\
0.024\end{array}$ & $\begin{array}{l}0.854 \\
0.058\end{array}$ & $-2,669.932$ & $\begin{array}{l}0.903 \\
0.010\end{array}$ & $* * *$ & $\begin{array}{r}-1.757 \\
0.193\end{array}$ & $* * *$ \\
\hline Norway spruce & $\begin{array}{r}13.086 \\
0.108\end{array}$ & $\begin{array}{r}-1.878 \\
0.033\end{array}$ & $\begin{array}{l}1.222 \\
0.219\end{array}$ & -639.428 & $\begin{array}{l}0.962 \\
0.004\end{array}$ & $* * *$ & $\begin{array}{r}-2.168 \\
0.564\end{array}$ & $* * *$ \\
\hline Silver fir & $\begin{array}{r}12.621 \\
0.108\end{array}$ & $\begin{array}{r}-1.779 \\
0.032\end{array}$ & $\begin{array}{l}0.853 \\
0.083\end{array}$ & -658.444 & $\begin{array}{l}0.006 \\
0.007\end{array}$ & $* * *$ & $\begin{array}{r}-1.797 \\
0.273\end{array}$ & $* * *$ \\
\hline Douglas fir & $\begin{array}{r}12.133 \\
0.189\end{array}$ & $\begin{array}{r}-1.646 \\
0.057\end{array}$ & $\begin{array}{l}1.128 \\
0.141\end{array}$ & -511.402 & $\begin{array}{l}0.941 \\
0.012\end{array}$ & $* * *$ & $\begin{array}{r}-2.061 \\
0.371\end{array}$ & $* * *$ \\
\hline
\end{tabular}

Standard errors are in italics. LRT $_{1}$ corresponds to the likelihood ratio test between the model fitted by OLS and the stochastic frontier model fitted by maximum likelihood (significance of a left-tailed distribution for the residuals). LRT 2 corresponds to the likelihood ratio test of $\mu$ (existence of a mode in the left-tailed distribution of residuals)

ns non-significant

$* * * p<0.001 ; * * p<0.01 ; * p<0.05$

2009). The aim of our study was not to investigate variations in the self-thinning relationship with site con-

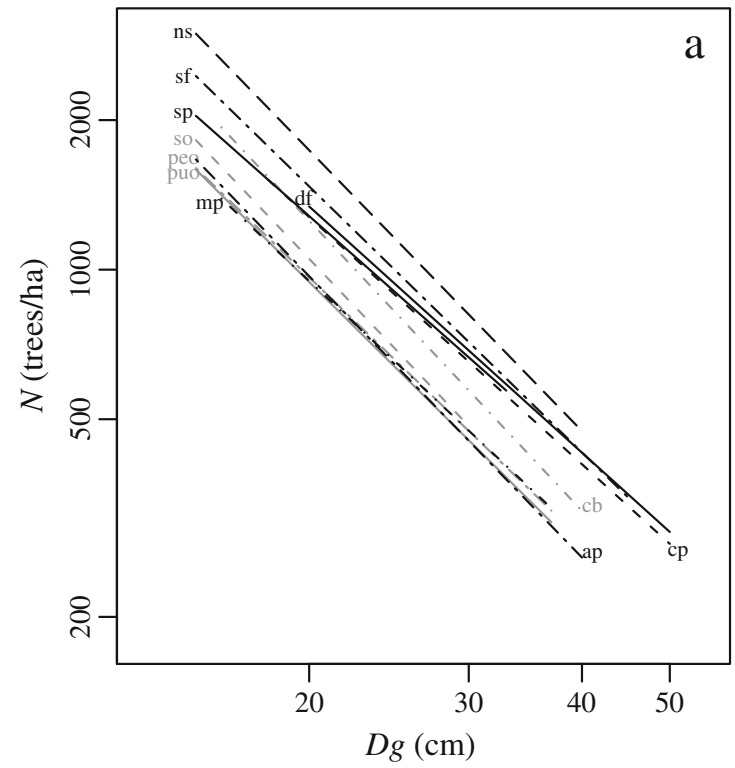

Fig. 2 a Fits of linear relationships plotted on a log-log scale for the 11 species studied. b Comparison of the allometric coefficients of selfthinning estimates obtained by removing the intercept to Eq. 1. puo ditions but to estimate and compare the maximum species boundaries (sensu Weller 1990) over their distributional

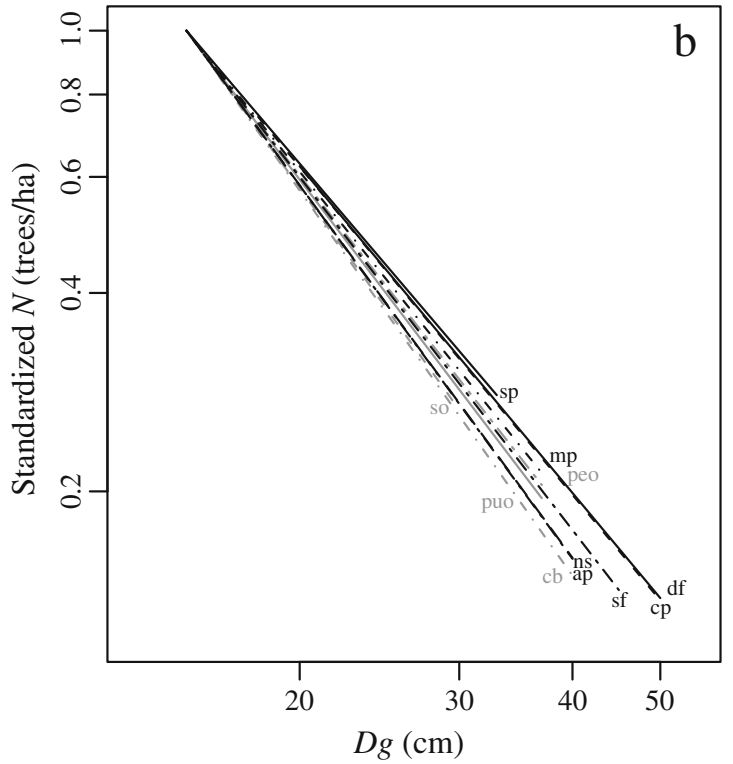

pubescent oak, peo pedunculate oak, so sessile oak, $c b$ common beech, $s p$ Scots pine, ap Aleppo pine, $c p$ Corsican pine, $m p$ maritime pine, $n s$ Norway spruce, $s f$ silver fir, $d f$ Douglas fir 
Table 3 Between-species differences in the allometric coefficients of self-thinning as assessed from a Student's $t$ test

\begin{tabular}{|c|c|c|c|c|c|c|c|c|c|c|}
\hline & $\begin{array}{l}\text { Scots } \\
\text { pine }\end{array}$ & $\begin{array}{l}\text { Douglas } \\
\text { fir }\end{array}$ & $\begin{array}{l}\text { Corsican } \\
\text { pine }\end{array}$ & $\begin{array}{l}\text { Maritime } \\
\text { pine }\end{array}$ & $\begin{array}{l}\text { Pedunc. } \\
\text { oak }\end{array}$ & $\begin{array}{l}\text { Silver } \\
\text { fir }\end{array}$ & $\begin{array}{l}\text { Pubesc. } \\
\text { oak }\end{array}$ & $\begin{array}{l}\text { Norway } \\
\text { spruce }\end{array}$ & $\begin{array}{l}\text { Aleppo } \\
\text { pine }\end{array}$ & $\begin{array}{l}\text { Sessile } \\
\text { oak }\end{array}$ \\
\hline Scots pine & $n s$ & & & & & & & & & \\
\hline Douglas fir & $n s$ & $n s$ & & & & & & & & \\
\hline Corsican pine & * & $n s$ & $n s$ & & & & & & & \\
\hline Maritime pine & $*$ & $n s$ & $n s$ & $n s$ & & & & & & \\
\hline Pedunculate oak & $* * *$ & $*$ & $*$ & $*$ & $n s$ & & & & & \\
\hline Siver fir & $*$ & $n s$ & $n s$ & $n s$ & $n s$ & $n s$ & & & & \\
\hline Pubescent oak & $* * *$ & $* * *$ & $* *$ & $* * *$ & $*$ & $*$ & $n s$ & & & \\
\hline Norway spruce & $* *$ & $* *$ & $*$ & $*$ & $n s$ & $n s$ & $n s$ & $n s$ & & \\
\hline Aleppo pine & $* * *$ & $* * *$ & $* *$ & $* * *$ & $*$ & $*$ & $n s$ & $n s$ & $n s$ & \\
\hline Sessile oak & $* * *$ & $* * *$ & $* * *$ & $* * *$ & $* *$ & $* * *$ & $n s$ & $n s$ & $n s$ & $n s$ \\
\hline
\end{tabular}

$n s$ non-significant

$* * * p<0.001 ; * * p<0.01 ; * p<0.05$

range in France. However, imbalances in site conditions over the diameter range may induce biases or artificial curvature in the self-thinning relationship estimates. We controlled for these imbalances using the French biophysical classification of forests (Inventaire Forestier National 2009; see Section 2).

\subsection{Relative position of linear self-thinning relationships}

The maximum attainable density is known to be positively related to species shade tolerance (Jack and Long 1996). The species ranking at $D_{\mathrm{g}}=20 \mathrm{~cm}$ showed a significant positive correlation $(r=0.62, p=0.04)$ with the degree of shade tolerance (Niinemets and Valladares, 2006; http:// www.esapubs.org/archive/mono/M076/020/appendix-A. htm). As shade-tolerant species, Norway spruce, silver fir and common beech displayed self-thinning relationships that occupied a higher position in the $\ln N-\ln D_{\mathrm{g}}$ plane (Fig. 2) than those of light-demanding pine and oak species. However, Douglas fir, Scots pine and Corsican pine reached unexpectedly high maximum densities given their low shade tolerance, suggesting that factors other than light resource may favour stocking (Shirley 1943; Zeide 1985). The specific differences in crown allometry and growing space efficiency might also be a promising perspective in the understanding of specific differences in the self-thinning relationship (Pretzsch and Schutze 2005). Indeed, recent works have pointed out that these specific characteristics affected the packing capacity of a stand. Pretzsch and Schutze (2005) observed that common beech had higher space occupancy than Norway spruce and was less efficient in space exploitation due to differences in branching and resource allocation. This was shown to affect the maximum stocking (Schütz and Zingg 2010).

\subsection{Species variations in allometric coefficient} of self-thinning

The significant between-species differences in the selfthinning allometric coefficient invalidate the hypothesis of a constant coefficient among species. The species classifications with respect to the allometric coefficient estimates were similar for 3 species to the classifications of Pretzsch and Biber (2005) who used long-term experimental data from fully stocked stands: common beech $<$ Norway spruce $<$ Scots pine. This remarkable agreement confirms the reliability of NFI data for such assessment and indicates some proximity between the self-thinning boundary sensu

Table 4 Groups of species of non-significantly differing allometric self-thinning coefficients (based on Table 3)

\begin{tabular}{|c|c|c|c|c|c|c|c|c|c|c|}
\hline $\begin{array}{l}\text { Scots } \\
\text { pine }\end{array}$ & $\begin{array}{l}\text { Douglas } \\
\text { fir }\end{array}$ & $\begin{array}{l}\text { Corsican } \\
\text { pine }\end{array}$ & $\begin{array}{l}\text { Maritime } \\
\text { pine }\end{array}$ & $\begin{array}{l}\text { Pedunc. } \\
\text { oak }\end{array}$ & $\begin{array}{l}\text { Silver } \\
\text { fir }\end{array}$ & $\begin{array}{l}\text { Pubesc. } \\
\text { oak }\end{array}$ & $\begin{array}{l}\text { Norway } \\
\text { spruce }\end{array}$ & $\begin{array}{l}\text { Aleppo } \\
\text { pine }\end{array}$ & $\begin{array}{l}\text { Sessile } \\
\text { oak }\end{array}$ & $\begin{array}{l}\text { Common } \\
\text { beech }\end{array}$ \\
\hline \multirow[t]{4}{*}{ A } & A & $\mathrm{A}$ & & & & & & & & \\
\hline & B & B & B & B & & & & & & \\
\hline & & & & $\mathrm{C}$ & $\mathrm{C}$ & $\mathrm{C}$ & & & & \\
\hline & & & & & & $\mathrm{D}$ & $\mathrm{D}$ & $\mathrm{D}$ & $\mathrm{D}$ & $\mathrm{D}$ \\
\hline
\end{tabular}

Each group is identified by a unique letter 
Table 5 Parameter estimates and goodness of fits for curvilinear models of self-thinning relationships

\begin{tabular}{|c|c|c|c|c|c|c|c|c|c|c|}
\hline & $\begin{array}{l}\text { Intercept } \\
\text { (trees/ha) }\end{array}$ & $\ln D_{\mathrm{g}}(\mathrm{cm})$ & $\ln D_{\mathrm{g}}^{2}(\mathrm{~cm})$ & $\sigma^{2}$ (trees $/$ ha $)$ & $\log \mathrm{Lik}$ & $\gamma$ & $\mathrm{LRT}_{1}$ & $\mu$ (trees/ha) & $\mathrm{LRT}_{2}$ & $\begin{array}{l}\mathrm{LRT}_{3} \text { or } \\
\triangle \mathrm{AIC}\end{array}$ \\
\hline Common beech & $\begin{array}{l}9.790 \\
0.058\end{array}$ & & $\begin{array}{r}-0.296 \\
0.005\end{array}$ & $\begin{array}{l}1.359 \\
0.116\end{array}$ & $-1,446.128$ & $\begin{array}{l}0.948 \\
0.007\end{array}$ & $* * *$ & $\begin{array}{r}-2.270 \\
0.271\end{array}$ & $* * *$ & -11.450 \\
\hline Scots pine & $\begin{array}{l}2.279 \\
1.624\end{array}$ & $\begin{array}{l}4.701 \\
1.047\end{array}$ & $\begin{array}{r}-1.023 \\
0.169\end{array}$ & $\begin{array}{l}1.368 \\
0.286\end{array}$ & $-3,121.937$ & $\begin{array}{l}0.934 \\
0.012\end{array}$ & $* * *$ & $\begin{array}{r}-1.410 \\
0.592\end{array}$ & $* * *$ & $* * *$ \\
\hline Aleppo pine & $\begin{array}{l}9.575 \\
0.166\end{array}$ & & $\begin{array}{r}-0.299 \\
0.013\end{array}$ & $\begin{array}{l}0.602 \\
0.160\end{array}$ & -560.725 & $\begin{array}{l}0.859 \\
0.034\end{array}$ & $* * *$ & $\begin{array}{l}0.212 \\
0.394\end{array}$ & $n s$ & -4.030 \\
\hline Maritime pine & $\begin{array}{l}9.307 \\
0.034\end{array}$ & & $\begin{array}{r}-0.272 \\
0.003\end{array}$ & $\begin{array}{l}0.843 \\
0.089\end{array}$ & $-2,665.869$ & $\begin{array}{l}0.900 \\
0.012\end{array}$ & $* * *$ & $\begin{array}{r}-1.742 \\
0.292\end{array}$ & $* * *$ & -8.120 \\
\hline Silver fir & $\begin{array}{l}4.700 \\
0.923\end{array}$ & $\begin{array}{l}3.000 \\
0.557\end{array}$ & $\begin{array}{r}-0.718 \\
0.084\end{array}$ & $\begin{array}{l}0.773 \\
0.104\end{array}$ & -638.180 & $\begin{array}{l}0.941 \\
0.009\end{array}$ & $* * *$ & $\begin{array}{r}-1.705 \\
0.360\end{array}$ & $* * *$ & $* * *$ \\
\hline Norway Spruce & $\begin{array}{r}10.043 \\
0.063\end{array}$ & & $\begin{array}{r}-0.287 \\
0.005\end{array}$ & $\begin{array}{l}1.259 \\
0.123\end{array}$ & -636.381 & $\begin{array}{l}0.964 \\
0.005\end{array}$ & $* * *$ & $\begin{array}{r}-2.203 \\
0.295\end{array}$ & $* * *$ & -6.100 \\
\hline Douglas fir & $\begin{array}{l}0.607 \\
1.095\end{array}$ & $\begin{array}{l}5.192 \\
0.638\end{array}$ & $\begin{array}{r}-1.009 \\
0.094\end{array}$ & $\begin{array}{l}1.146 \\
0.154\end{array}$ & -503.321 & $\begin{array}{l}0.944 \\
0.009\end{array}$ & $* * *$ & $\begin{array}{r}-2.080 \\
0.417\end{array}$ & $* * *$ & $* * *$ \\
\hline
\end{tabular}

Standard errors are in italics. $\mathrm{LRT}_{1}$ and $\mathrm{LRT}_{2}$ are as in Table 3. $\mathrm{LRT}_{3}$ corresponds to the likelihood ratio test of the quadratic term when relevant (see Section 3). $\triangle \mathrm{AIC}$ is provided when considering models with the same number of parameters

$n s$ non-significant

$* * * p<0.001 ; * * p<0.01 ; * p<0.05$

Weller (1990) and the dynamic self-thinning trajectory of a given species. The slope estimate we found for sessile oak was not the flattest as in Pretzsch and Biber (2005), but this disagreement might be due to the short diameter range covered by our dataset for this species. Groups of nondistinguishable species were identified (up to five species, Table 4), highlighting the necessity of a large number of

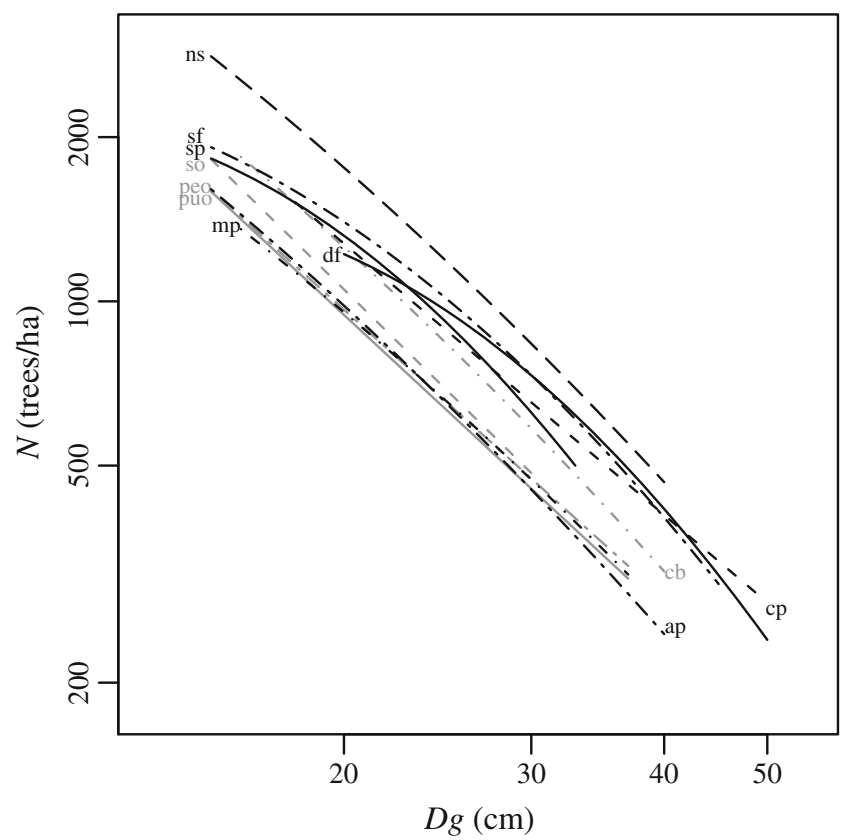

Fig. 3 Fits of the curvilinear relationships found significant among the species studied plotted on a $\log -\log$ scale. Otherwise, linear relationship. Species abbreviations are as in Fig. 2 species to avoid selection biases and properly address the issue. As a main outcome of this study, the existence of non-overlapping groups definitely confirms significant differences in the self-thinning relationship between species.

Despite the common classification with Pretzsch and Biber (2005) for three species, our slope estimates were all steeper by $1-12.8 \%$. A formal comparison between their

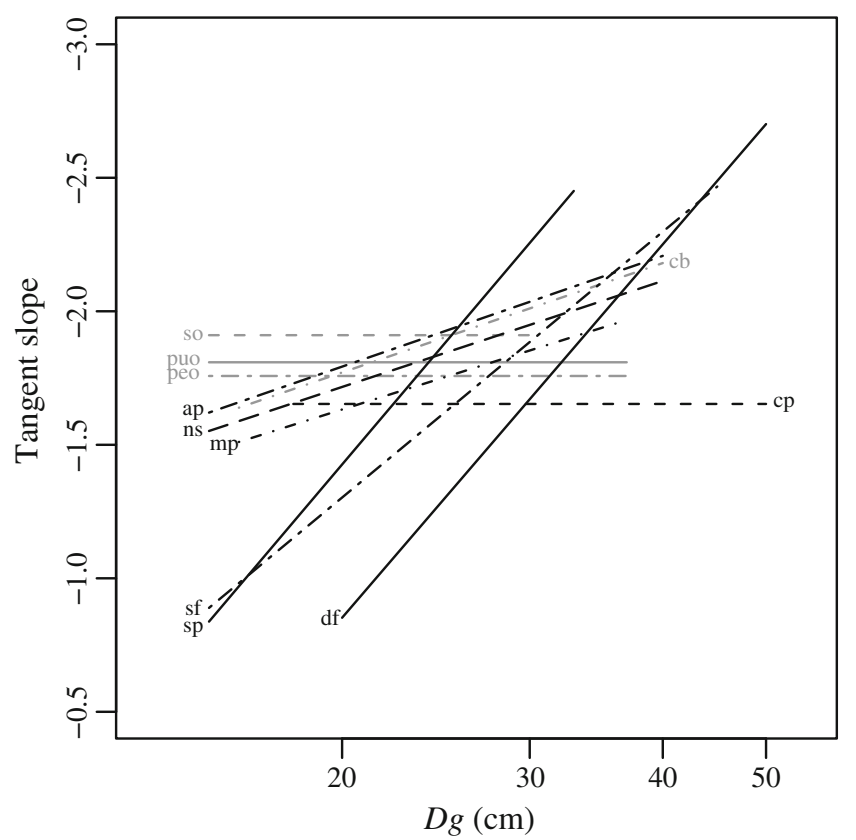

Fig. 4 Variation of the tangent slope of the curvilinear self-thinning relationships with quadratic mean diameter. Species abbreviations are as in Fig. 2 
dynamic self-thinning trajectories and our maximum selfthinning boundaries is difficult. However, the minimum mean diameters in their study were below $15 \mathrm{~cm}$ for the four species (from 5.7 to $13.4 \mathrm{~cm}$ ). The curvilinearity of the $\ln N-\ln D_{\mathrm{g}}$ relationship evidenced in this study may explain the difference as it would generate flatter slope estimates with lower diameter thresholds and a linear assumption. This might, however, not be the only explanation as the slope we found for sessile oak was steeper, albeit without curvature.

Stand origin was shown to affect the slope of the selfthinning line for Douglas fir, with planted stands having a flatter slope (Weiskittel et al. 2009). In France, Douglas fir is only found in plantations, which may result in an artificially lower slope than for the other species. Corsican and maritime pines are also mostly planted, but a few naturally regenerated stands may be found in the resource as we observed dense young stands (Fig. 1). Their slope estimates might thus not be biased.

\subsection{Curvilinearity of the self-thinning relationship}

For 7 out of 11 species, the self-thinning relationship was better represented by a quadratic relationship of $\ln D_{\mathrm{g}}$ than a linear one. This highlighted the effect of developmental stage on the self-thinning rate. Curvilinearity of the selfthinning relationship has previously been evidenced for common beech, Norway spruce (Pretzsch 2006; Schütz and Zingg 2010) and Scots pine (Pretzsch 2006). Interestingly, we confirmed the allometric relationship found for sessile oak (Pretzsch 2006). Zeide (2010) suggested an interpretation for the increasing self-thinning rate with stand ageing: (1) as trees get bigger, the gaps created by dead trees widen and (2) in parallel, their higher metabolic cost of maintenance and reduced photosynthetic activity (Yoder et al. 1994) would make bigger trees less able to react to canopy openings. Consequently, an opening in old stands would lead to overstocked yet relatively sparser stands. Although Nilson's (1973) model has been shown to be particularly appropriate to account for the continuous increase in the self-thinning rate with developmental stage (Zeide 2010), it could not be tested with the SFA method because of its nonlinearity in the parameters. The quadratic term in $\ln D_{\mathrm{g}}$ used here also resulted in a curvature of the self-thinning relationship with tree diameter.

5.6 Comparison of species self-tolerance over developmental stage

We found that self-tolerance decreases with developmental stage for several species. The decrease varied from very strong (Scots pine, Douglas fir and silver fir) to null (Corsican pine, pedunculate, pubescent and sessile oaks; Fig. 4), leading to a dramatic change in the ranking of species self-tolerance over developmental stage. This suggests that absolute species comparisons are not meaningful.

Variations in species maximum density with developmental stage have implications for the dynamics of mixedspecies communities whose stability or evolution towards pure communities may depend on the relative maximal densities that the admixed species can each tolerate (Shaw 2006). The significant differences in species self-thinning relationships and in their ordering over ontogeny (Figs. 3 and 4) suggest that the dynamics of corresponding mixtures may vary over time. Given that species also differ in their intrinsic growth rate (Lambers and Poorter 1992), a comprehensive assessment of the dynamical consequences of self-thinning variations among tree species, including laws of diameter growth, remains to be conducted.

\section{Conclusion}

Using stochastic frontier analysis, we fitted self-thinning allometries for 11 temperate species from NFI data. As a main outcome, we confirm that the self-thinning relationship significantly varies across species, from a comparison of the allometric coefficients over a high number of species. We further identified a departure from the allometric assumption in the self-thinning relationships of most species, a finding that has never been shown on such an extensive dataset. The suggested effect of developmental stage on the self-tolerance of tree species has potential significance for the dynamics and stability of mixed-species communities.

Acknowledgements The authors wish to thank the French NFI for providing the data. The anonymous reviewers are also thanked for their helpful comments on a previous version of the manuscript.

Funding This work was funded by INRA.

\section{References}

Aigner D, Lovell CAK, Schmidt P (1977) Formulation and estimation of stochastic frontier production function models. J Econom 6:21-37

Bailey RG, Pfister RD, Henderson JA (1978) Nature of land and resource classification - review. J Forest 76:650-655

Battese GE, Corra GS (1977) Estimation of a production frontier model - with application to pastoral zone of eastern Australia. Aust J Agric Econ 21:169-179

Bi HQ (2004) Stochastic frontier analysis of a classic self-thinning experiment. Austral Ecol 29:408-417

Bi HQ, Wan GG, Turvey ND (2000) Estimating the self-thinning boundary line as a density-dependent stochastic biomass frontier. Ecology 81:1477-1483 
Burnham KP, Anderson DR (2002) Model selection and multimodel inference: a practical information-theoretic approach. Springer, New York, p 497

Coelli T (1995) Estimators and hypothesis tests for a stochastic frontier function - a Monte-Carlo analysis. J Prod Anal 6:247268

Coelli T (1996) A guide to FRONTIER version 4.1: a computer program for stochastic frontier production and cost function estimation. Working Paper 96/07, Center for Efficiency and Productivity Analysis, University of New England, Armidale, Australia, p 33

Coelli T, Henningsen A (2010) Package 'frontier' - stochastic frontier analysis. CRAN

Enquist BJ (2002) Universal scaling in tree and vascular plant allometry: toward a general quantitative theory linking plant form and function from cells to ecosystems. Tree Physiol 22:1045-1064

Gorham E (1979) Shoot height, weight and standing crop in relation to density of monospecific plant stands. Nature 279:148-150

Inventaire Forestier National (2009) Les sylvoécorégions (SER) de France métropolitaine_Etude de définition, p 166. http:// www.ifn.fr/spip/IMG/pdf/Rapport_ser.pdf. Accessed 10 May 2011.

Jack SB, Long JN (1996) Linkages between silviculture and ecology: an analysis of density management diagrams. Forest Ecol Manag $86: 205-220$

Lambers H, Poorter H (1992) Inherent variation in growth-rate between higher-plants - a search for physiological causes and ecological consequences. Adv Ecol Res 23:187-261

Le Goff N, Ottorini JM (1999) Effects of thinning on beech growth. Interaction with climatic factors. Rev Forest Fr 50:355-364 (in French)

Le Goff N, Ottorini JM, Ningre F (2010) Evaluation and comparison of size-density relationships for pure even-aged stands of ash (Fraxinus excelsior L.), beech (Fagus silvatica L.), oak (Quercus petraea Liebl.) and sycamore (Acer pseudoplatanus L.). Ann For Sci 68:461-475

Niinemets U, Valladares F (2006) Tolerance to shade, drought, and waterlogging of temperate Northern Hemisphere trees and shrubs. Ecol Monogr 76:521-547

Nilson A (1973) On the theory of programming of thinnings. Collect Estonian Agric Acad Sci 89:136-142 (in Estonian)

Pretzsch H (2006) Species-specific allometric scaling under selfthinning: evidence from long-term plots in forest stands. Oecologia 146:572-583

Pretzsch H (2009) Forest dynamics, growth and yield. Springer, Berlin, pp 41-99

Pretzsch H, Biber P (2005) A re-evaluation of Reineke's rule and stand density index. Forest Sci 51:304-320
Pretzsch H, Schutze G (2005) Crown allometry and growing space efficiency of Norway spruce (Picea abies L. Karst.) and European beech (Fagus sylvatica L.) in pure and mixed stands. Plant Biol 7:628-639

Puettmann KJ, Hann DW, Hibbs DE (1993) Evaluation of the sizedensity relationships for pure red alder and Douglas-fir stands. Forest Sci 39:7-27

R Development Core Team (2009) R: a language and environment for statistical computing. R foundation for statistical computing, Vienna, Austria

Reineke LH (1933) Perfecting a stand-density index for even-aged forests. J Agric Res 46:627-638

Robert N, Vidal C, Colin A, Herve JC, Hamza N, Cluzeau C (2010) France. In: Tomppo E, Gschwantner T, Lawrence M, McRoberts RE (eds) National Forest Inventories - pathways for common reporting. Springer, Heidelberg, pp 207-221

Schütz J-P, Zingg A (2010) Improving estimations of maximal stand density by combining Reineke's size-density rule and the yield level, using the example of spruce (Picea abies (L.) Karst.) and European beech (Fagus sylvatica L.). Ann For Sci 67:507

Shaw JD (2006) Reineke's stand density index: where are we and where do we go from here? Proceedings of the Society of American Foresters 2005 National Convention, Ft. Worth, TX, 2006, p 13 (published on CD_ROM, Bethesda MD, Society of American Foresters)

Shirley HL (1943) Is tolerance the capacity to endure shade? J Forest 41:339-345

Weiskittel A, Gould P, Temesgen H (2009) Sources of variation in the self-thinning boundary line for three species with varying levels of shade tolerance. Forest Sci 55:84-93

Weller DE (1987) A reevaluation of the $-3 / 2$ power rule of plant selfthinning. Ecol Monogr 57:23-43

Weller DE (1990) Will the real self-thinning rule please stand up - a reply. Ecology 71:1204-1207

White J (1980) Demographic factors in populations of plants. In: Solbrig OT (ed) Demography and evolution in plant populations. Blackwell, Oxford, pp 21-48

Yoda K, Kira T, Ogawa H, Hozumi K (1963) Self-thinning in overcrowded pure stands under cultivated and natural conditions. J Biol Osaka City U 14:107-129

Yoder BJ, Ryan MG, Waring RH, Schoettle AW, Kaufmann MR (1994) Evidence of reduced photosynthetic rates in old trees. Forest Sci 40:513-527

Zeide B (1985) Tolerance and self-tolerance of trees. Forest Ecol Manag 13:149-166

Zeide B (2010) Comparison of self-thinning models: an exercise in reasoning. Trees-Struct Funct 24:1117-1126

Zhang LJ, Bi HQ, Gove JH, Heath LS (2005) A comparison of alternative methods for estimating the self-thinning boundary line. Can J For Res 35:1507-1514 